\title{
Biochemical changes in the jejunal mucosa of dogs with a naturally occurring enteropathy associated with bacterial overgrowth
}

\author{
R M BATT, M W CARTER, AND T J PETERS \\ From the Department of Veterinary Pathology, University of Liverpool, Liverpool; and Division of Clinical \\ Cell Biology, MRC Clinical Research Centre, Harrow, Middlesex
}

SUMMARY The subcellular biochemical features of a naturally occurring enteropathy in the dog associated with bacterial overgrowth have been examined. Affected animals comprised a group of 10 German Shepherd dogs with raised serum folate and reduced vitamin $\mathrm{B}_{12}$ concentrations, mild steatorrhoea, reduced xylose absorption, and normal exocrine pancreatic function. Culture of duodenal juice showed bacterial overgrowth with mixed flora, most frequently including enterococci and Escherichia coli. Examination of peroral jejunal biopsies revealed predominantly minimal histological but distinct biochemical abnormalities in the mucosa. The specific activity of alkaline phosphatase was decreased, isopycnic density gradient centrifugation showing a marked loss particularly of the brush border component of enzyme activity. In contrast, $\gamma$-glutamyl transferase activity was enhanced in brush border fragments of slightly increased modal density, but there were no changes in the activities of the carbohydrases, zinc-resistant $\alpha$-glucosidase, maltase, sucrase, and lactase or of the peptidase, leucyl-2naphthylamidase. Activities of lysosomal enzymes were increased and there was evidence for enhanced lysosomal fragility and mitochondrial disruption. The activities and density gradient distributions of marker enzymes for basal-lateral membranes, endoplasmic reticulum and peroxisomes were essentially unaltered. These findings show that bacterial colonisation of the proximal small intestine may be associated with specific alterations in microvillus membrane proteins and provide biochemical evidence for intracellular damage to the enterocytes.

Many anatomical and functional disorders may be associated with bacterial overgrowth in the small intestine in $\operatorname{man}^{1-6}$ and in experimental animals, ${ }^{5-8}$ but the precise role of bacteria in the pathogenesis of mucosal abnormalities is not clearly defined. Particular attention has been focused on the blind loop syndrome where it is now recognised that mucosal injury may make a significant contribution to the malabsorption of nutrients, ${ }^{568-14}$ previously considered to be solely a consequence of intraluminal disturbance. Possible mechanisms of mucosal damage have been explored, for example certain brush border abnormalities have been related to direct effects of bacterial proteases on

Address for correspondence: Dr R M Batt. Department of Veterinary Pathology, University of Liverpool. PO Box 147. Liverpool L69 3BX.

Received for publication 2 November 1983 specific microvillus membrane proteins. ${ }^{15} 16$ The situation is complex, however, and it is not clear why some changes can only be partially corrected by antibiotic therapy. ${ }^{8}$ Indeed, the long term consequences of small bowel colonisation are ill defined and their possible contribution to the pathogenesis of severe mucosal abnormalities, such as those of chronic tropical sprue, are not well understood. ${ }^{17-19}$ This study presents a naturally occurring enteropathy in the dog that provides a new approach to the investigation of the complex inter-relationship between an abnormal flora and mucosal damage. A preliminary report has been published. ${ }^{20}$

\section{Methods}

CLINICAL INVESTIGATIONS

The animals with small intestinal disease comprised 
10 German Shepherd dogs, one aged nine years and the remainder aged between five months and two years. All animals had been referred for an investigation of chronic diarrhoea, with or without loss of weight, and had exhibited clinical signs for at least three months, two cases since they were one year old and the other dogs since they were approximately two months old. Details of the routine screening procedures have been presented previously with relevant control data, ${ }^{21} 22$ and the findings are summarised in Table 1. All affected animals had raised serum folate concentrations and, excluding one animal given parenteral vitamin $\mathrm{B}_{12}$, reduced serum vitamin $B_{12}$ concentrations. Erythrocyte folate concentration was raised in one animal but the increase in the group mean concentration was not statistically significant $(p=0 \cdot 06)$. Functional evidence for malabsorption by the affected group was provided by showing mild steatorrhoea and a reduced mean plasma xylose concentration after oral xylose. All animals had normal exocrine pancreatic function, assessed by the oral administration of N-benzoyl-L-tyrosyl-paminobenzoic $\operatorname{acid}^{21}$ or by the assay of serum trypsin-like immunoreactivity. ${ }^{23}$ Faecal examination revealed ova of Toxocara $\mathrm{sp}$ in one case, and Giardia sp were seen in the faeces and duodenal juice of two other dogs. Routine haematology showed neutrophilia $\left(>11.5 \times 10^{9} / 1\right)$ in one dog, lymphopenia $\left(<1.0 \times 10^{9} / 1\right)$ in a second dog and eosinophilia $\left(>1.25 \times 10^{9} / 1\right)$ in three other animals, none of which had evidence of parasite infestation. Routine clinical biochemistry revealed no abnormalities. Barium contrast radiographic studies were performed on eight dogs and revealed no gross anatomical abnormalities of the stomach or small intestine.

After fasting for approximately 18 hours, jejunal biopsies were obtained from a site just distal to the duodenal-jejunal flexure using either a single or multiple biopsy capsule. ${ }^{24}$ Examination by dissecting and conventional light microscopy revealed minimal changes apart from partial villous atrophy in biopsies from two animals. In seven dogs, duodenal juice was obtained through the tubing of the multiple capsule, positioned with the tip just proximal to the duodenal flexure, and subjected to quantitative and qualitative bacteriological studies as described previously. ${ }^{25}$ Viable counts were greater than $10^{5}$ organisms per $\mathrm{ml}$ of duodenal juice (Table 2) and confirmed the presence of a bacterial overgrowth suggested by the high serum folate and reduced vitamin $B_{12}$ concentrations. ${ }^{25}$ The organisms responsible for the overgrowth varied, but enterococci (including Streptococcus faecalis) and Escherichia coli were the most frequent isolates.

\section{BIOCHEMICAL STUDIES}

Portions of jejunal biopsies (approximately 10-50 $\mathrm{mg}$ ) were homogenised in sucrose medium $(0.3$ $\mathrm{mol} / \mathrm{l}$ sucrose, $22 \mathrm{mmol} / \mathrm{l}$ ethanol, $1 \mathrm{mmol} / 1 \mathrm{Na}_{2}$ EDTA, pH 7.4) and a postnuclear supernatant subjected to analytical subcellular fractionation by sucrose density gradient centrifugation as described previously. ${ }^{26}$ After centrifugation alkaline phosphatase was assayed immediately then the gradient fractions were stored at $-20^{\circ} \mathrm{C}$ before further assay. Results are expressed in the form of frequencydensity histograms the averaging of distributions being performed by computer. ${ }^{27}$ Marker enzymes for the principal subcellular organelles were assayed as described previously. ${ }^{26}{ }^{28}$. Maltase, sucrase, and lactase were assayed ${ }^{29}$ in portions of biopsies collected in deionised water and disrupted in a Dounce homogeniser (Kontes Glass Co, Vineland, New Jersey, USA) with 20 strokes of a type B pestle. Protein was determined according to Schacterle and Pollack ${ }^{30}$ with bovine serum albumin (Armour Pharmaceutical Co, Chicago, USA) as standard. Control animals were clinically healthy dogs (age six months-10 years; median two years) with no functional or histological evidence of jejunal abnormality. Student's $t$ test was used to assess the significance of differences between the control and affected groups.

Table 1 Summary of routine screening procedures performed on the animals with small intestinal disease.

\begin{tabular}{|c|c|c|c|c|c|}
\hline Group & $\begin{array}{l}\text { Serum folate } \\
(\mu g / l)\end{array}$ & $\begin{array}{l}\text { Erythrocyte } \\
\text { folate } \\
(\mu \mathrm{g} / \mathrm{l})\end{array}$ & $\begin{array}{l}\text { Serum } \\
\text { vitamin } B_{12} \\
(\text { ng } / l)\end{array}$ & $\begin{array}{l}\text { Fat excretion } \\
\text { (\% of intake) }\end{array}$ & $\begin{array}{l}\text { Peak plasma } \\
\text { xylose } \\
(\mathrm{mmol} / \mathrm{l})\end{array}$ \\
\hline Intestinal disease & $20 \cdot 8 \pm 3 \cdot 9(10)$ & $296 \pm 40(9)$ & $128 \pm 11(9)$ & $12 \cdot 5 \pm 1 \cdot 3(8)$ & $4 \cdot 6 \pm 0 \cdot 40(10)$ \\
\hline Control & $\begin{array}{l}8 \cdot 9 \pm 0 \cdot 6(20) \\
(4 \cdot 8-13 \cdot 0)\end{array}$ & $\begin{array}{l}230 \pm 13(20) \\
(160-350)\end{array}$ & $\begin{array}{l}277 \pm 14(20) \\
(200-400)\end{array}$ & $\begin{array}{l}6 \cdot 6 \pm 0 \cdot 5(15) \\
(3-10)\end{array}$ & $\begin{array}{l}5 \cdot 5 \pm 0 \cdot 2(15) \\
(4 \cdot 5-6 \cdot 4)\end{array}$ \\
\hline Statistical significance $(p)$ & $<0 \cdot 001$ & NS & $<0 \cdot 001$ & $<0 \cdot 001$ & $<0 \cdot 05$ \\
\hline
\end{tabular}

Data are expressed as mean \pm SEM with the numbers of animals and control ranges in parentheses. Statistical analysis by Student's $t$ test. $\mathrm{NS}=$ not significant $(\mathrm{p}>0 \cdot 05)$. 
Table 2 Bacterial flora in duodenal juice of dogs with small intestinal disease

\begin{tabular}{lll}
\hline Case no & $\begin{array}{l}\text { Viable count } \\
(\text { per ml) }\end{array}$ & Organisms \\
\hline 1 & $1.6 \times 10^{7}$ & Streptococcus faecalis \\
& $6.0 \times 10^{6}$ & Escherichia coli \\
& $1.0 \times 10^{5}$ & Staphylococcus citreus \\
2 & $2.5 \times 10^{6}$ & Escherichia coli \\
& $9.2 \times 10^{5}$ & Enterococci \\
& $1.6 \times 10^{5}$ & Acinetobacter anitratus \\
& $2.0 \times 10^{4}$ & Enterococci \\
& $2.0 \times 10^{4}$ & Staphylococcus epidermidis \\
4 & $>3.0 \times 10^{7}$ & Clostridium spp. ${ }^{*}$ \\
& $>4.0 \times 10^{6}$ & Bifidobacterium spp. $^{*}$ \\
& $3.2 \times 10^{6}$ & Escherichia coli \\
& $5.2 \times 10^{5}$ & Enterococci \\
5 & $6.4 \times 10^{6}$ & Clostridium spp. ${ }^{*}$ \\
& $3.0 \times 10^{5}$ & Escherichia coli \\
6 & $6.7 \times 10^{5}$ & Clostridium spp. ${ }^{*}$ \\
& $2.5 \times 10^{4}$ & Escherichia coli \\
& $1.6 \times 10^{4}$ & Enterococci \\
& $5.0 \times 10^{3}$ & Streptomyces spp. \\
7 & $4.4 \times 10^{5}$ & Staphylococcus epidermidis \\
& $3.7 \times 10^{4}$ & Staphylococcus aureus \\
Control ${ }^{\dagger}$ & $<2.0 \times 10^{4}$ &
\end{tabular}

* Denotes obligate anaerobes.

+ From reference 25 .

\section{Results}

ENZYME ACTIVITIES

Compared with the control group there are distinct differences in the activities of specific brush border enzymes in jejunal biopsies from the animals with small intestinal disease (Table 3). Alkaline phosphatase activity is markedly reduced and $\gamma$-glutamyl transferase activity is increased. In contrast, there are no changes in the activities of zinc resistant $\alpha$-glucosidase, maltase, sucrase, lactase, or leucyl-2naphthylamidase. The specific activities of marker enzymes for the other principal subcellular organelles are shown in Table 4 . The activities of certain lysosomal marker enzymes ( $\mathrm{N}$-acetyl- $\beta$ glucosaminidase, acid phosphatase, but not $\alpha$ mannosidase) are increased in biopsies from the affected group. There are no changes, however, in the activities of $5^{\prime}$ nucleotidase (basal-lateral membranes), malate dehydrogenase (mitochondria, cytosol) tris-resistant $\alpha$-glucosidase (endoplasmic reticulum) or catalase (peroxisomes).

\section{ANALYTICAL SUBCELLULAR FRACTIONATION}

The Figure shows the relative specific activities and density gradient distributions of marker enzymes in jejunal biopsies from control and affected animals. The activities and distributions of the brush border enzymes zinc resistant $\alpha$-glucosidase and leucyl-2naphthylamidase are comparable in the two groups, but there is a slight shift in the modal density of the particulate component of these enzymes from 1.20 in the control to 1.21 in the affected group. This density change is reflected in the distribution of $\gamma$-glutamyl transferase indicating that the enhanced activity of this enzyme is predominantly associated with brush border fragments of increased density. In contrast, the distribution of alkaline phosphatase clearly shows a marked reduction in the brush border component of this enzyme activity in biopsies from affected animals. There is a loss of the major brush border peak of modal density 1.19 present in the control animals. The residual activity has a broad shallow distribution, with shoulders at densities 1.12 and 1.18 corresponding approximately with the peak activities of the basal-lateral membrane and endoplasmic reticular marker enzymes respectively.

The density distributions of $5^{\prime}$ nucleotidase (basal-lateral membranes) are not markedly different comparing the control and the affected groups. The subcellular distributions of $\mathrm{N}$-acetyl- $\beta$ glucosaminidase, however, are distinctly different, for although the particulate lysosomal activities are almost identical there is a marked increase in soluble

Table 3 Activities of brush border marker enzymes in jejunal biopsies from animals with intestinal disease and controls

\begin{tabular}{|c|c|c|c|c|c|c|c|}
\hline $\begin{array}{l}\text { Enzyme } \\
\text { EC no }\end{array}$ & $\begin{array}{l}\text { Zinc-resistant } \\
\alpha \text {-glucosidase } \\
3.2 .1 .20\end{array}$ & $\begin{array}{l}\text { Maltase } \\
3.2 .1 .20\end{array}$ & $\begin{array}{l}\text { Sucrase } \\
3.2 .1 .48\end{array}$ & $\begin{array}{l}\text { Lactase } \\
3.2 .1 .23\end{array}$ & $\begin{array}{l}\text { Alkaline } \\
\text { phosphatase } \\
\text { 3.1.3.1 }\end{array}$ & $\begin{array}{l}\text { Leucyl-2- } \\
\text { naphthylamidase } \\
3.4 .11 .1\end{array}$ & $\begin{array}{l}\gamma \text {-Glutamyl } \\
\text { transferase } \\
2.3 .2 .2\end{array}$ \\
\hline Intestinal disease & $\begin{array}{l}6 \cdot 2 \pm 0 \cdot 7 \\
(10)\end{array}$ & $\begin{array}{l}331 \pm 44 \\
(10)\end{array}$ & $\begin{array}{l}79 \pm 10 \\
(10)\end{array}$ & $\begin{array}{l}24 \cdot 9 \pm 3 \cdot 6 \\
(10)\end{array}$ & $\begin{array}{l}77 \cdot 3 \pm 14 \\
(10)\end{array}$ & $\begin{array}{l}86 \cdot 5 \pm 8 \cdot 5 \\
(10)\end{array}$ & $\begin{array}{l}19 \cdot 2 \pm 4 \cdot 6 \\
(10)\end{array}$ \\
\hline Control & $\begin{array}{l}6 \cdot 2 \pm 0 \cdot 2 \\
(17)\end{array}$ & $\begin{array}{l}329 \pm 25 \\
(12)\end{array}$ & $\begin{array}{l}67 \pm 5 \cdot 1 \\
(12)\end{array}$ & $\begin{array}{l}33 \cdot 5 \pm 3 \cdot 8 \\
(12)\end{array}$ & $\begin{array}{l}134 \pm 9 \cdot 8 \\
(15)\end{array}$ & $\begin{array}{l}102 \pm 8 \cdot 5 \\
(16)\end{array}$ & $\begin{array}{l}10 \cdot 9 \pm 0 \cdot 5 \\
(15)\end{array}$ \\
\hline $\begin{array}{l}\text { Statistical } \\
\quad \text { significance }(p)\end{array}$ & NS & NS & NS & NS & $<0 \cdot 01$ & NS & $<0 \cdot 04$ \\
\hline
\end{tabular}

Data $(\mathrm{mU} / \mathrm{mg}$ protein) are expressed as mean \pm SEM with the number of animals in parentheses.

Statistical analysis by Student's $t$ test .

$\mathrm{NS}=$ not significant $(\mathrm{p}>0 \cdot 05)$. 
Table 4 Activities of marker enzymes in jejunal biopsies from animals with intestinal disease and controls

\begin{tabular}{|c|c|c|c|c|c|c|c|}
\hline $\begin{array}{l}\text { Enzyme } \\
\text { EC no }\end{array}$ & $\begin{array}{l}\text { 5' nucleotidase } \\
3.1 .3 .5\end{array}$ & $\begin{array}{l}N \text {-acetyl- } \beta \text { - } \\
\text { glucosaminidase } \\
3.2 .1 .30\end{array}$ & $\begin{array}{l}\text { Acid } \\
\text { phosphatase } \\
3.1 .3 .2\end{array}$ & $\begin{array}{l}\alpha-\text { mannosidase } \\
3.2 .1 .24\end{array}$ & $\begin{array}{l}\text { Malate } \\
\text { dehydrogenase } \\
1.1 .1 .37\end{array}$ & $\begin{array}{l}\text { Tris-resistant } \\
\alpha \text {-glucosidase } \\
3.2 .1 .20\end{array}$ & $\begin{array}{l}\text { Catalase } \\
1.11 .1 .6\end{array}$ \\
\hline $\begin{array}{r}\text { Intestinal } \\
\text { disease }\end{array}$ & $\begin{array}{l}3 \cdot 5 \pm 0 \cdot 9 \\
(10)\end{array}$ & $\begin{array}{l}4 \cdot 3 \pm 0 \cdot 2 \\
(9)\end{array}$ & $\begin{array}{l}8 \cdot 0 \pm 1 \cdot 2 \\
(9)\end{array}$ & $\begin{array}{l}1 \cdot 3 \pm 0 \cdot 1 \\
(9)\end{array}$ & $\begin{array}{l}2730 \pm 190 \\
(10)\end{array}$ & $\begin{array}{l}0 \cdot 7 \pm 0 \cdot 02 \\
(10)\end{array}$ & $\begin{array}{l}7 \cdot 5 \pm 1 \cdot 1 \\
(9)\end{array}$ \\
\hline Control & $\begin{array}{l}2 \cdot 7 \pm 0 \cdot 3 \\
(12)\end{array}$ & $\begin{array}{l}3 \cdot 6 \pm 0 \cdot 2 \\
(16)\end{array}$ & $\begin{array}{l}4 \cdot 0 \pm 0 \cdot 4 \\
(12)\end{array}$ & $\begin{array}{l}1 \cdot 2 \pm 0 \cdot 1 \\
(16)\end{array}$ & $\begin{array}{l}2510 \pm 230 \\
(11)\end{array}$ & $\begin{array}{l}0 \cdot 7 \pm 0 \cdot 04 \\
(16)\end{array}$ & $\begin{array}{l}8 \cdot 6 \pm 0 \cdot 7 \\
(16)\end{array}$ \\
\hline $\begin{array}{l}\text { Statistical } \\
\quad \text { significance }(p)\end{array}$ & NS & $<0.04$ & $<0.01$ & NS & NS & NS & NS \\
\hline
\end{tabular}

Data (mU/mg protein) are expressed as mean $\pm \mathrm{SEM}$ with the number of animals in parentheses.

Statistical analysis by Student's $t$ test.

$\mathrm{NS}=$ not significant $(\mathrm{p}>0 \cdot(05)$.

activity in the group with intestinal disease. The specific activity of malate dehydrogenase is unaltered in this group, but the density gradients show some reduction in the particulate mitochondrial component and an increase in the soluble component of this enzyme activity. The distribution of tris-resistant $\alpha$-glucosidase (endoplasmic reticulum) shows a shift in the modal density of the particulate component towards the denser fractions in the group with intestinal disease. The activities and density distributions of catalase (peroxisomes, not shown) revealed negligible differences between the two groups.

\section{Discussion}

The application of serum folate and vitamin $B_{12}$ estimations to the investigation of naturally occurring malabsorption in the dog has assisted the diagnosis of chronic small intestinal abnormalities in this species. ${ }^{22} \mathrm{As}$ in man, a raised serum folate accompanied by a reduced serum vitamin $B_{12}$ concentration has been shown to be associated with a bacterial overgrowth in the proximal small intestine ${ }^{25}$ and the present study has examined the subcellular biochemical changes in the jejunal mucosa of affected animals.

Light microscopy revealed morphological abnormalities comparable to those described in the blind loop syndrome in $\operatorname{man}^{10}$ and in experimental animals $^{9}{ }_{1-13} 31$ where villous atrophy can be a consequence of bacterial overgrowth but most frequently histological changes are minimal. Ultrastructural changes, ${ }^{9-11}$ impaired monosaccharide transport, ${ }^{9}$ and biochemical abnormalities, ${ }^{8}{ }^{12-14} 32$ however, have been well documented and provide definite evidence for mucosal damage in the blind loop syndrome. Similarly, in this study there were striking biochemical changes in the mucosa particularly in the brush border where there were distinct but selective alterations in the activities of specific marker enzymes. In the affected group the activities of the carbohydrases, zinc resistant $\alpha$-glucosidase, maltase, sucrase and lactase and of the peptidase, leucyl-2-naphthylamidase, were unchanged. The specific activity of alkaline phosphatase was decreased, however, subcellular fractionation showing a marked loss particularly of the brush border component of enzyme activity, while $\gamma$ glutamyl transferase activity was increased. These findings contrast markedly with the brush border changes described in the experimental blind loop syndrome where damage appears to be less specific and disaccharidase activities in particular are generally reduced ${ }^{5} 812-1432$ although alkaline phosphatase activity can be relatively spared. ${ }^{32}$ These apparent differences may be related not only to the numbers but also to the types of bacteria isolated. In the blind loop syndrome there are considerably increased numbers particularly of obligate anaerobes, notably Bacteroides and Clostridium spp, whereas in the present study viable counts were generally lower than in the blind loop syndrome and aerobic rather than anaerobic organisms frequently predominated. Indeed anaerobes have been specifically implicated in the disaccharidase deficiences of the experimental blind loop syndrome and are thought to increase brush border degradation of these enzymes ${ }^{32}$ either by their release from $^{15}$ or destruction in the membrane. ${ }^{16}$ In a recent study, ${ }^{33}$ however, it was suggested by Schjonsby $e$ t al that extrapolation from the experimental to the human blind loop syndrome was largely speculative and had not previously been pursued by the assay of mucosal enzymes. Indeed their findings in patients with the blind loop syndrome were in closer agreement with the present study, for although alkaline phosphatase activity was not reduced, activities of carbohydrases and of leucyl-2-naphthylamidase also appeared unaffected and $\gamma$-glutamyl transferase activity was increased. ${ }^{33}$

The effects of bacteria on alkaline phosphatase 
Figure Isopycnic centrifugation of postnuclear supernatant fraction from jejunal biopsy specimens from control (solid line) and affected animals (stippled). Graphs show the relative frequencydensity distributions of eight marker enzymes. For each enzyme areas of distributions comparing the two groups are proportional to enzyme specific activity. Frequency is defined as that portion of total recovered activity present in individual fraction divided by density span covered by that fraction.

Relative frequency

(mean $\pm S E M, n=5$ ) was derived by multiplying frequency data for affected animals by relative specific activity ( $\mathrm{mU} / \mathrm{mg}$ protein) of these affected compared with control animals. Percentage recoveries for control and affected animals respectively, with relative specific activities between parentheses, are: zincresistant $\alpha$-glucosidase 81,84 $(1 \cdot 2)$; alkaline phosphatase 58 , $70(0 \cdot 4)$; leucyl-2-

naphthylamidase 79, $73(1 \cdot 0)$; $\gamma$-glutamyl transferase 84,88 (I.5); $5^{\prime}$ nucleotidase 79,88 (0.9); $N$-acetyl- $\beta$ -

glucosaminidase 68, $70(1 \cdot 3)$; malate dehydrogenase 87,83 $(1 \cdot 1)$; tris-resistant $\alpha$ glucosidase 107, $98(1 \cdot 0)$.
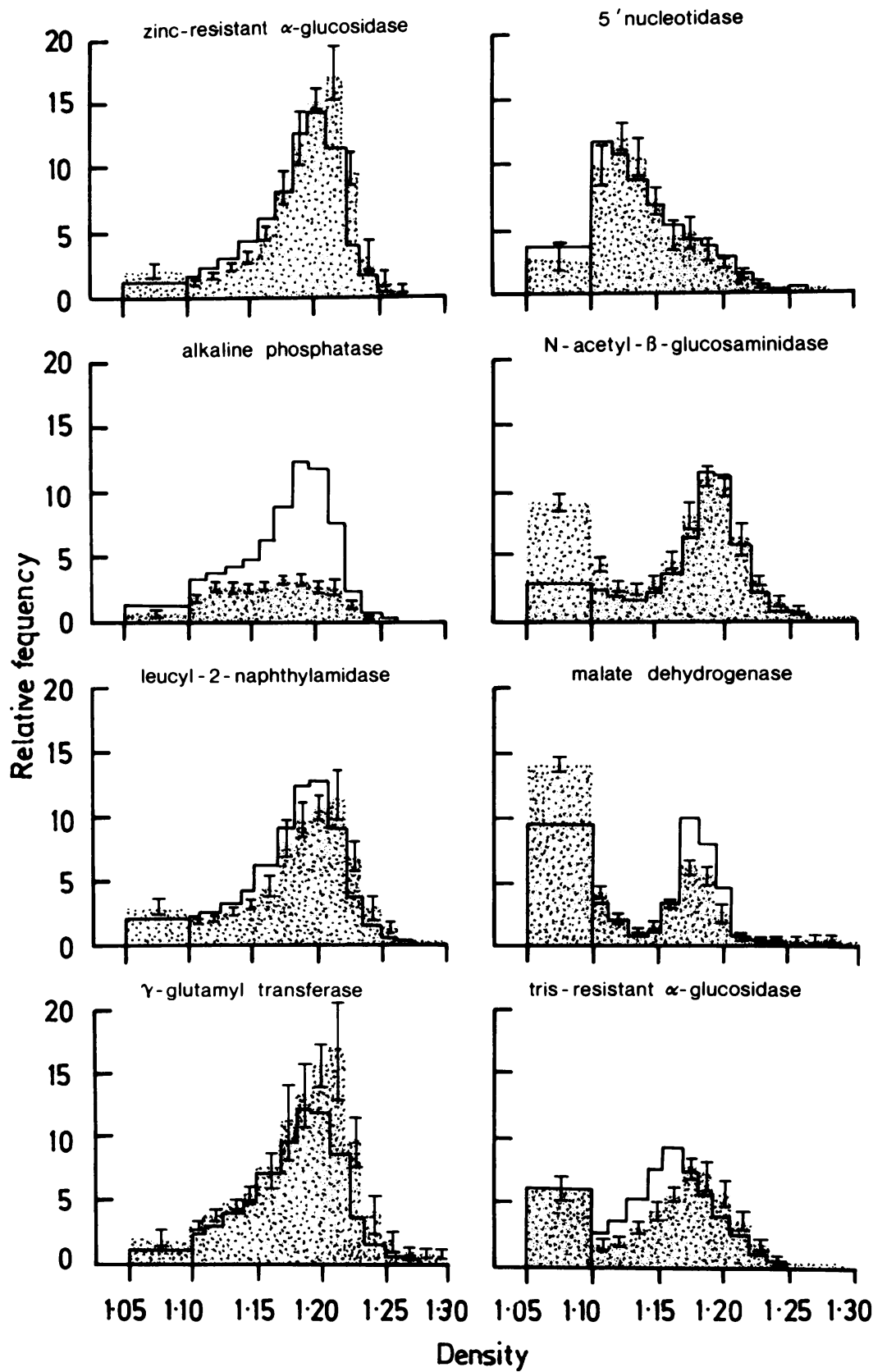

activity appear to be variable, for although in the experimental blind loop syndrome reduced levels have been described ${ }^{1314}$ brush border activity may not be affected..$^{32}$ Susceptibility to degradative enzymes may depend not only on the accessibility of appropriate bonds to attack but also on their importance in maintaining either the active conformation of the enzyme or its attachment to the microvillus membrane. Alkaline phosphatase does appear to be less susceptible than the disaccharidases to release either by proteases or detergent ${ }^{34-37}$ apparently consistent with a relative resistance to bacterial degradation. ${ }^{15} 1632$ Although only a relatively small proportion was released, however, a 
$75 \%$ loss of alkaline phosphatase activity was observed when brush borders were incubated with an extract from Clostridium perfringens. ${ }^{15}$ This suggests that destruction in situ rather than release might be more relevant to the degradation of alkaline phosphatase by specific bacteria, and this property could be pertinent to the specific loss of brush border activity in the present study. Possible mechanisms include direct damage by bacteria or their secreted products, and the metabolism of intraluminal contents to potentially toxic products, for example deconjugated bile salts and hydroxy fatty acids. ${ }^{5}$ These may have a direct effect on the enzyme, or could act by perturbation of associated membrane lipids resulting in an alteration of the hydrophobic domain. In these affected dogs other factors, however, including a decrease in the rate of enzyme synthesis, and perhaps zinc deficiency, ${ }^{38}$ could be responsible for the low activity of alkaline phosphatase in the microvillus membrane.

The effects of bacteria on brush border peptidases have received relatively little attention; however, in the experimental blind loop syndrome they may be affected by non-specific damage to the brush border. ${ }^{13} 39$ In the present study, not only the disaccharidases but also the activity of the peptidase leucyl-2-naphthylamidase appeared to be unaffected in the dogs with intestinal disease. In marked contrast, there was an increase in the activity of brush border $\gamma$-glutamyl transferase: the reason for this is not clear, but a specific inductive change does seem more likely than a decreased rate of degradation. Intraluminal disturbances ${ }^{5}$ might act as a stimulus, and this response could be beneficial in a potentially hostile environment, a possibility discussed in relation to the increased activities of this enzyme in certain neoplastic tissues. ${ }^{40}$ High levels of $\gamma$-glutamyl transferase have also been found in association with secreted immunoglobulins, but the suggestion that this enzyme represents secretory component ${ }^{41}$ has been refuted. ${ }^{42}$ Consequently, although a role in translocation remains a possibility, ${ }^{43}$ at present the functional significance of this enzyme in the small intestine remains uncertain. Interestingly, raised $\gamma$-glutamyl transferase activities have been documented in biopsies from human patients with the blind loop syndrome, and it has been suggested that this finding might reflect enhanced proliferative activity. ${ }^{33}$

The basal-lateral membranes appeared to be relatively unaffected in the present study, supporting the suggestion that intraluminal events may be of particular importance in the derivation of the specific changes at the exposed surface of the enterocyte plasma membrane. There was evidence for intracellular damage, however, particularly affecting the lysosomes and mitochondria. Activities of specific lysosomal enzymes were enhanced and for $\mathrm{N}$-acetyl- $\beta$-glucosaminidase this increase was associated with the soluble fractions of the density gradients, a finding suggestive of an increased lysosomal fragility. Enhanced lysosomal enzyme activity has been shown histochemically in the experimental blind loop syndrome ${ }^{13}$ but lysosomal changes are not specific and have been described in other intestinal diseases. ${ }^{44-46}$ The mitochondrial component of malate dehydrogenase activity was reduced and the soluble component increased, consistent with release of matrix contents because of mitochondrial damage, an ultrastructural change documented in the blind loop syndrome. ${ }^{91013}$ The increased modal density of the endoplasmic reticular marker enzyme suggested a greater proportion of rough to smooth endoplasmic reticulum in enterocytes from affected dogs. This could reflect a relatively enhanced rate of synthesis of proteins destined for export or membrane insertion. ${ }^{47}$ Indeed it is possible that, apart from alkaline phosphatase, enhanced synthesis might have compensated for any increased loss of protein from the brush border, as has been suggested for the less contaminated segments in the experimental blind loop syndrome. ${ }^{32}$ This could be a consequence of a more mature population of enterocytes, although bacteria might be expected to have the reverse effect by accelerating the turnover and migration of enterocytes. ${ }^{48}$ Vitamin $B_{12}$ deficiency, however, should not be ignored as this can have an effect on the jejunal mucosa $^{49}$ and may have contributed to the biochemical changes described here.

This study emphasises that the absence of distinct histological abnormalities does not exclude the possibility of damage to the small intestinal mucosa, an observation stressed previously particularly in the blind loop syndrome..$^{9-11}$ The changes contrasted markedly with those described recently in older dogs with an enteropathy resembling chronic tropical sprue in $\operatorname{man}^{46}$ in which villous atrophy was accompanied by generalised biochemical damage to the microvillus membrane. As the German Shepherd breed seems to be particularly susceptible to both diseases it is conceivable that long standing overgrowth might result in these more serious and perhaps irreversible mucosal changes, a possibility discussed in man. ${ }^{5} 19$ The possible derivation of the overgrowth has been discussed in detail previously; ${ }^{25}$ although disordered motility and achlorhydria cannot be excluded, preliminary studies do suggest that there may be an underlying immunological disorder. ${ }^{50}$

The authors are grateful to the Wellcome Trust, the 
BSAVA Clinical Studies Trust Fund, the German Shepherd Dog League, and the Canine Supporters Charity for financial support. We also thank Mr J R Needham for assistance with the bacteriology, Mr P White for technical assistance, and Mrs P Laws for typing the manuscript.

\section{References}

1 Prizont R, Hersh T, Floch MH. Jejunal bacterial flora in chronic small bowel disease. I Celiac disease, II Regional enteritis. Am J Clin Nutr 1970; 23: 1602-7.

2 Coello-Ramirez P, Lifshitz F, Zuniga V. Enteric microflora and carbohydrate intolerance in infants with diarrhea. Pediatrics 1972; 49: 233-42.

3 Campbell CB, Cowen AE, Harper J. Duodenal bacterial flora and bile salt patterns in patients with gastrointestinal disease. Aust NZ J Med 1973; 3: 339-48.

4 Greenlee HB, Gelbart SM, De Orio AJ, Francescatti DS, Paez J, Reinhardt GF. The influence of gastric surgery on the intestinal flora. Am J Clin Nutr 1977; 30: 1826-33.

5 King CE, Toskes PP. Small intestine bacterial overgrowth. Gastroenterology 1979; 76: 1035-55.

6 Banwell JG, Kistler LA, Giannella RA, Weber FL Jr, Lieber A, Powell DE. Small intestinal bacterial overgrowth syndrome. Gastroenterology 1981; 80: 834 45.

7 Bernstein LH, Gutstein S, Efron G, Wager G. Experimental production of elevated serum folate in dogs with intestinal blind loops: relationship of serum levels to location of the blind loop. Gastroenterology 1972; 63: 815-9.

8 Giannella RA, Rout WR, Toskes PP. Jejunal brush border injury and impaired sugar and amino acid uptake in the blind loop syndrome. Gastroenterology 1974; 67: 965-74.

9 Gracey M, Burke V, Oshin A, Barker J, Glasgow EF. Bacteria, bile salts, and intestinal monosaccharide malabsorption. Gut 1971; 12: 683-92.

10 Ament ME, Shimoda SS, Saunders DR, Rubin CE. Pathogenesis of steatorrhea in three cases of small intestinal stasis syndrome. Gastroenterology 1972; 63: 728-47.

11 Gracey M, Papadimitriou J, Bower G. Ultrastructural changes in the small intestines of rats with self-filling blind loops. Gastroenterology 1974; 67: 646-51.

12 Bloch R, Menge M, Lorenz-Meyer H, Stöckert HG, Riecken EO. Functional, biochemical and morphological alterations in the intestines of rats with an experimental blind loop syndrome. Res Exp Med 1975; 166: $67-8$.

13 Toskes PP, Giannella RA, Jervis HR, Rout WR, Takeuchi A. Small intestinal mucosal injury in the experimental blind loop syndrome: light and electronmicroscopic and histochemical studies. Gastroenterology 1975; 68: 1193-203.
14 Gracey M, Thomas J, Houghton M. Effect of stasis on intestinal enzyme activities. Aust NZ J Med 1975; 5: 141-4.

15 Jonas A, Krishnan C, Forstner G. Pathogenesis of mucosal injury in the blind loop syndrome. Release of disaccharidases from brush border membranes by extracts of bacteria obtained from intestinal blind loops in rats. Gastroenterology 1978; 75: 791-5.

16 Riepe SP, Goldstein J, Alpers DH. Effect of secreted Bacteroides proteases on human intestinal brush border hydrolases. J Clin Invest 1980; 66: 314-22.

17 Gorbach SL, Banwell JG, Jacobs B et al. Tropical sprue and malnutrition in West Bengal. 1 Intestinal microflora and absorption. Am J Clin Nutr 1970; 23: 1545-58.

18 Gorbach SL. Intestinal microflora. Gastroenterology 1971; 60: 1110-29.

19 Klipstein FA, Holdeman LV, Corcini JJ, Moore WEC. Enterotoxigenic intestinal bacteria in tropical sprue. Ann Intern Med 1973; 79: 632-41.

20 Batt RM, Carter MW, Peters TJ. Subcellular biochemical changes in the jejunal mucosa of dogs with naturally occurring bacterial overgrowth. Clin Sci 1982; 63: $55 \mathrm{P}$.

21 Batt RM, Mann LC. The specificity of the BT-PABA test for the diagnosis of exocrine pancreatic insufficiency in the dog. Vet Rec 1981; 108: 303-7.

22 Batt RM, Morgan JO. Role of serum folate and vitamin $B_{12}$ concentrations in the differentiation of small intestinal abnormalities in the dog. Res $\mathrm{Vet} S \mathrm{Ci}$ 1982; 32: 17-22.

23 Williams DA, Batt RM. Diagnosis of canine exocrine pancreatic insufficiency by the assay of serum trypsinlike immunoreactivity. J Small Anim Pract 1983; 24: 583-8.

24 Batt RM. Techniques for single and multiple peroral jejunal biopsy in the dog. J Small Anim Pract 1979; 20: 259-68.

25 Batt RM, Needham JR, Carter MW. Bacterial overgrowth associated with a naturally occurring enteropathy in the German shepherd dog. Res Vet Sci 1983; 35: $42-6$.

26 Batt RM, Peters TJ. Subcellular fractionation studies on peroral jejunal biopsies from the dog. Res Vet Sci 1978; 25: 94-100.

27 Leighton F, Poole B, Beaufay $\mathrm{H}$ et al. The large-scale separation of peroxisomes, mitochondria and lysosomes from the liver of rats injected with Triton WR 1339. J Cell Biol 1968; 37: 482-513.

28 Batt RM, Bush BM, Peters TJ. Biochemical changes in the jejunal mucosa of dogs with naturally occurring exocrine pancreatic insufficiency. Gut 1979; 20: 709-15.

29 Peters TJ, Batt RM, Heath JR, Tilleray J. The microassay of intestinal disaccharidases. Biochem Med 1976; 15: 145-8.

30 Schacterle GR, Pollack RL. A simplified method for the quantitative assay of small amounts of protein in biologic material. Anal Biochem 1973; 51: 654-5.

31 Hoet PP, Eyssen H. Steatorrhoea in rats with an intestinal cul-de-sac. Gut 1964; 5: 309-14.

32 Jonas A, Flanagan PR, Forstner GG. Pathogenesis of mucosal injury in the blind loop syndrome. Brush 
border enzyme activity and glycoprotein degradation. $J$ Clin Invest 1977; 60: 1321-30.

33 Schjønsby $\mathrm{H}$, Anderson K-J, Nordgård K, Skagen DW. Enzymatic activities in jejunal specimens from patients with the stagnant-loop syndrome. Scand $J$ Gastroenterol 1983; 18: 599-602.

34 Eichholz A. Studies on the organization of the brush border in intestinal epithelial cells. V Subfractionation of enzymatic activities of the microvillus membrane. Biochem Biophys Acta 1968; 163: 101-7.

35 Critchley DR, Howell KE, Eichholz A. Solubilization of brush borders of hamster small intestine and fractionation of some of the components. Biochem Biophys Acta 1975; 394: 361-76.

36 Louvard D, Maroux S, Vannier Ch, Desnuelle P. Topological studies on the hydrolases bound to the intestinal brush border membrane. 1 Solubilization by papain and triton X-100. Biochem Biophys Acta 1975; 375: $236-48$.

37 Colbeau A, Maroux S. Integration of alkaline phosphatase in the intestinal brush border membrane. Biochem Biophys Acta 1978; 511: 39-51.

38 Davies NT, Flett AA. The similarity between alkaline phosphatase (EC 3.1.3.1) and phytase (EC 3.1.3.8) activities in rat intestine and their importance in phytase-induced zinc deficiency. Br J Nutr 1978; 39: 307-16.

39 Mazzacca G, Musella S, Andria G, D’Agostino L, Cimino L, Budillon G. Brush border peptidases and arylamidases in the experimental blind loop syndrome of the rat. Acta Hepatogastroenterol 1977; 24: 364-7.

40 Vanderlaan M, Phares W. $\gamma$-Glutamyltranspeptidase: a tumour cell marker with a pharmacological function. Histochem J 1981; 13: 865-77.

41 Binkley F, Wiesemann ML, Hand WL et al. Evidence for the association of secretory immunoglobulin $\mathrm{A}$ and gamma glutamyl transferase. Fedn Proc 1975; 34: 513.
42 Brandtzaeg $P$, Winsnes A. Human secretory component - V Lack of association with $\gamma$-glutamyl transpeptidase in colostrum. Immunochemistry 1976; 13: $951-4$.

43 Tate SS, Meister A. $\gamma$-Glutamyl transpeptidase: catalytic, structural and functional aspects. Mol Cell Biochem 1981; 39: 357-68.

44 Peters TJ, Jones PE, Wells G. Analytical subcellular fractionation of jejunal biopsy specimens: enzyme activities, organelle pathology and response to gluten withdrawal in patients with coeliac disease. Clin Sci Mol Med 1978; 55: 285-92.

45 Peters TJ, Jones PE, Wells G, Cook GG. Sequential enzyme and subcellular fractionation studies on jejunal biopsy specimens from patients with post-infective tropical malabsorption. Clin Sci 1979; 56: 479-86.

46 Batt RM, Bush BM, Peters TJ. Subcellular biochemical studies of a naturally occurring enteropathy in the dog resembling chronic tropical sprue in human beings. $\mathrm{Am}$ $J$ Vet Res 1983; 44: 1492-6.

47 Dallner G, Siekevitz P, Palade GE. Biogenesis of endoplasmic reticulum membranes. I Structural and chemical differentiation in developing rat hepatocyte. $J$ Cell Biol 1966; 30: 73-96.

48 Mathan VI, Ponniah J, Mathan M. Tropical enteropathy: an adaptation of the small intestine to accelerated cell loss in 'contaminated' environments. In: Robinson JWL, Dowling RH, Riecken EO, eds. Mechanisms of intestinal adaptation. Lancaster: MTP Press, 1982: 609-10.

49 Arvanitakis C. Functional and morphological abnormalities of the small intestinal mucosa in pernicious anaemia - a prospective study. Acta Hepatogastroenterol 1978; 25: 313-8.

50 Whitbread TJ, Batt RM, Garthwaite G. A relative deficiency of serum IgA in the German shepherd dog: a breed abnormality. Res Vet Sci. (In press.) 